\title{
Current and future $\mathrm{G}$ protein-coupled receptor signaling targets for heart failure therapy
}

This article was published in the following Dove Press journal:

Drug Design, Development and Therapy

10 October 2013

Number of times this article has been viewed

\author{
Ashley Siryk-Bathgate \\ Samalia Dabul \\ Anastasios Lymperopoulos \\ Laboratory for the Study of \\ Neurohormonal Control of \\ the Circulation, Department of \\ Pharmaceutical Sciences, Nova \\ Southeastern University College of \\ Pharmacy, Fort Lauderdale, FL, USA
}

Correspondence: Anastasios Lymperopoulos Department of Pharmaceutical Sciences, Nova Southeastern University College of Pharmacy, 3200 S University Drive, HPD (Terry) Building/Room I338, Fort Lauderdale, FL 33328, USA

Tel + I 954262 I338

Fax + I 9542622278

Email al806@nova.edu

\begin{abstract}
Although there have been significant advances in the therapy of heart failure in recent decades, such as the introduction of $\beta$-blockers and antagonists of the renin-angiotensinaldosterone system, this devastating disease still carries tremendous morbidity and mortality in the western world. G protein-coupled receptors, such as $\beta$-adrenergic and angiotensin II receptors, located in the membranes of all three major cardiac cell types, ie, myocytes, fibroblasts, and endothelial cells, play crucial roles in regulation of cardiac function in health and disease. Their importance is reflected by the fact that, collectively, they represent the direct targets of over one-third of the currently approved cardiovascular drugs used in clinical practice. Over the past few decades, advances in elucidation of the signaling pathways they elicit, specifically in the heart, have led to identification of an increasing number of new molecular targets for heart failure therapy. Here, we review these possible targets for heart failure therapy that have emerged from studies of cardiac $\mathrm{G}$ protein-coupled receptor signaling in health and disease, with a particular focus on the main cardiac $G$ protein-coupled receptor types, ie, the $\beta$-adrenergic and the angiotensin II type 1 receptors. We also highlight key issues that need to be addressed to improve the chances of success of novel therapies directed against these targets.
\end{abstract}

Keywords: heart failure, G protein-coupled receptor, signaling, cardiac, therapeutic target

\section{Introduction}

Heart failure (HF) is a complex pathophysiological syndrome that arises from a primary defect in the ability of the heart to fill and/or eject blood sufficiently. The clinical manifestations of HF result from the primary myocardial insult (most commonly coronary artery disease, hypertension, or genetic factors) and the attendant sequelae. In general, the primary insult brings about an increase in myocardial wall stress that induces an orchestrated cascade of remodeling stimuli within the heart, as well as neurohormonal, vascular, renal, and skeletal muscle alterations. Within this conceptual framework, chronic HF is generally a progressive disorder that results from continued left ventricular (LV) remodeling and a progressive loss of function. It should be noted that abnormalities of systolic and/or diastolic function can result in similar symptoms and they might share some common underlying mechanisms. It is estimated that symptomatic HF currently affects $0.4 \%-2 \%$ of the general population in the western world. ${ }^{1-3}$ Importantly, however, the incidence of symptomatic HF rises substantially with increasing age; estimates of symptomatic HF prevalence for individuals over 65 years of age range between $6 \%$ and $10 \%$. $^{1,4,5} \mathrm{Up}$ to $50 \%$ of patients diagnosed with $\mathrm{HF}$ will die within 4 years, and for patients with end-stage $\mathrm{HF}$, the 1 year survival rate is $50 \%$ - worse than most advanced malignancies. ${ }^{6,7}$ 
The most important neurohormonal receptors that regulate cardiac function and physiology belong to the superfamily of $\mathrm{G}$ protein-coupled receptors (GPCRs) (or seven transmembrane-spanning receptors $[7 \mathrm{TMRs}]) .{ }^{8}$ For instance, cardiac function (contractility) is tightly controlled by the activity of $\beta$-adrenergic receptors ( $\beta_{1}$ - and $\left.\beta_{2} A R s\right)$ located in the membranes of cardiac myocytes. ${ }^{9}$ Cardiac structure and morphology are regulated by angiotensin II (AngII) type 1 receptors (AT $\mathrm{Rs}_{1}$ ) present (mainly) in cardiac fibroblast and endothelial cell membranes, but also, to a lesser extent, in cardiomyocyte membranes. ${ }^{8}$ Heart rate (HR) is modulated by the balance between the activities of $\beta$-adrenergic and muscarinic cholinergic ( $\mathrm{mAChR}$ ) receptors located in various anatomical segments of the cardiac electrical conduction system. ${ }^{8,9}$ Furthermore, even the neurohormonal control of the circulatory system, whether it be catecholamine and corticosteroid release by the adrenal glands or activation of the renin-angiotensin-aldosterone system (RAAS) by the juxtaglomerular apparatus of the kidneys or release of neurotransmitters by central and peripheral neurons innervating cardiovascular organs, is under tight regulation by various GPCRs (eg, $\alpha_{2}$ ARs) as well. ${ }^{8,9}$ Thus, given that signaling from all these cardiac GPCRs constitutes an integral part of regulation of cardiac function, it comes as no surprise that drugs directly targeting (ie, binding) these receptors represent over one-third of currently used cardiovascular drugs in clinical practice, and the vast majority of currently approved HF drugs target GPCR function and signaling in one way or another. ${ }^{8,9}$ However, there is still an enormous potential for development of novel HF therapies targeting these receptors, either directly (ie, the GPCR per se) or some other signaling molecule down the pathway the receptor activates. The cloning and molecular and structural characterizations of GPCRs, highlighted by last year's Nobel prize in chemistry award to the two pioneers of the field, Bob Lefkowitz and Brian Kobilka, ${ }^{10}$ has spurred many significant advances in delineation and understanding of cardiac GPCR signaling in health and disease over the past couple of decades. The present review will discuss, receptor and signaling molecule type-by-type, all the important findings in the field of cardiac GPCR signaling that can be harnessed for development of novel HF therapeutics, and will also highlight the salient issues that complicate exploitation of these GPCR signaling targets for future HF clinical therapies.

\section{BAR signaling targets for HF therapy}

The sympathetic nervous system (SNS) neurotransmitters norepinephrine (NE) and epinephrine (Epi) mediate their effects in cells and tissues by binding to specific cell surface adrenoceptors (ARs), three $\alpha_{1} \mathrm{ARs}$, three $\alpha_{2} \mathrm{ARs}$, and three $\beta$ ARs $\left(\beta_{1}, \beta_{2}, \beta_{3}\right){ }^{9}$ All ARs primarily signal through heterotrimeric $\mathrm{G}$ proteins. The human heart contains all three $\beta$ AR subtypes. ${ }^{9} \beta_{1} \mathrm{AR}$ is the predominant subtype in the (normal, healthy) myocardium, representing $75 \%-80 \%$ of total $\beta$ AR density; followed by $\beta_{2} \mathrm{AR}$, which accounts for about $15 \%-18 \%$ of total cardiomyocyte $\beta$ ARs; and the remaining $2 \%-3 \%$ is $\beta_{3}$ ARs (under normal conditions). ${ }^{9,11}$ The principal role of $\beta A R s$ in the heart is the regulation of cardiac rate and contractility in response to NE and Epi. Stimulation of $\beta_{1}$ ARs (mainly) and of $\beta_{2}$ ARs (to a lesser extent) increases cardiac contractility (positive inotropic effect), frequency (positive chronotropic effect), and rate of relaxation (lusitropic effect), and accelerates impulse conduction through the atrioventricular node (positive dromotropic effect) and pacemaker activity from the sinoatrial node. ${ }^{9} \beta_{3}$ ARs are predominantly inactive during normal physiologic conditions; ${ }^{12}$ however, their stimulation seems to produce a negative inotropic effect opposite to that induced by $\beta_{1}$ ARs and $\beta_{2} A R s$, involving the nitric oxide synthase (NOS) pathway, ${ }^{13}$ thus acting as a "fuse" against cardiac adrenergic overstimulation. ${ }^{14}$ The most powerful physiologic mechanism to increase cardiac performance is activation of cardiomyocyte $\beta_{1} \mathrm{ARs}$ and $\beta_{2} \mathrm{ARs}$, which, in turn, activates $\mathrm{G}_{\mathrm{s}}$ proteins (stimulatory $\mathrm{G}$ proteins). $\mathrm{G}_{\mathrm{s}}$ protein signaling stimulates the effector adenylate cyclase (AC), which converts adenosine triphosphate (ATP) to the second messenger adenosine $3^{\prime}, 5^{\prime}$-monophosphate or cyclic AMP (cAMP), which in turn binds to and activates the cAMP-dependent protein kinase (protein kinase A [PKA]). ${ }^{9}$ PKA is the major effector of cAMP and, by phosphorylating a variety of substrates, it ultimately results in a significant raise in free intracellular $\mathrm{Ca}^{2+}$ concentration, which is the master regulator of cardiac muscle contraction (Figure 1). ${ }^{15}$ Of note, PKA can phosphorylate the $\beta$ ARs themselves (and other GPCRs) in the heart, causing G protein uncoupling and functional desensitization of the receptor (heterologous or agonist-independent desensitization). ${ }^{16}$ Given that cAMP and PKA augment cardiac contractility, drugs that enhance signaling through these molecules (such as inhibitors of cAMP-specific phosphodiesterase, an enzyme that degrades cAMP and reduces PKA activation) have been developed for HF (Figure 1). ${ }^{17}$ Although they might be useful for acute decompensated $\mathrm{HF}$, when acute increases in contractility are needed to sustain life, these drugs increase mortality in human HF in the long run (possibly because they increase cardiac workload and oxygen demand) and are nowadays contraindicated in chronic HF. ${ }^{17}$ This is entirely consistent 

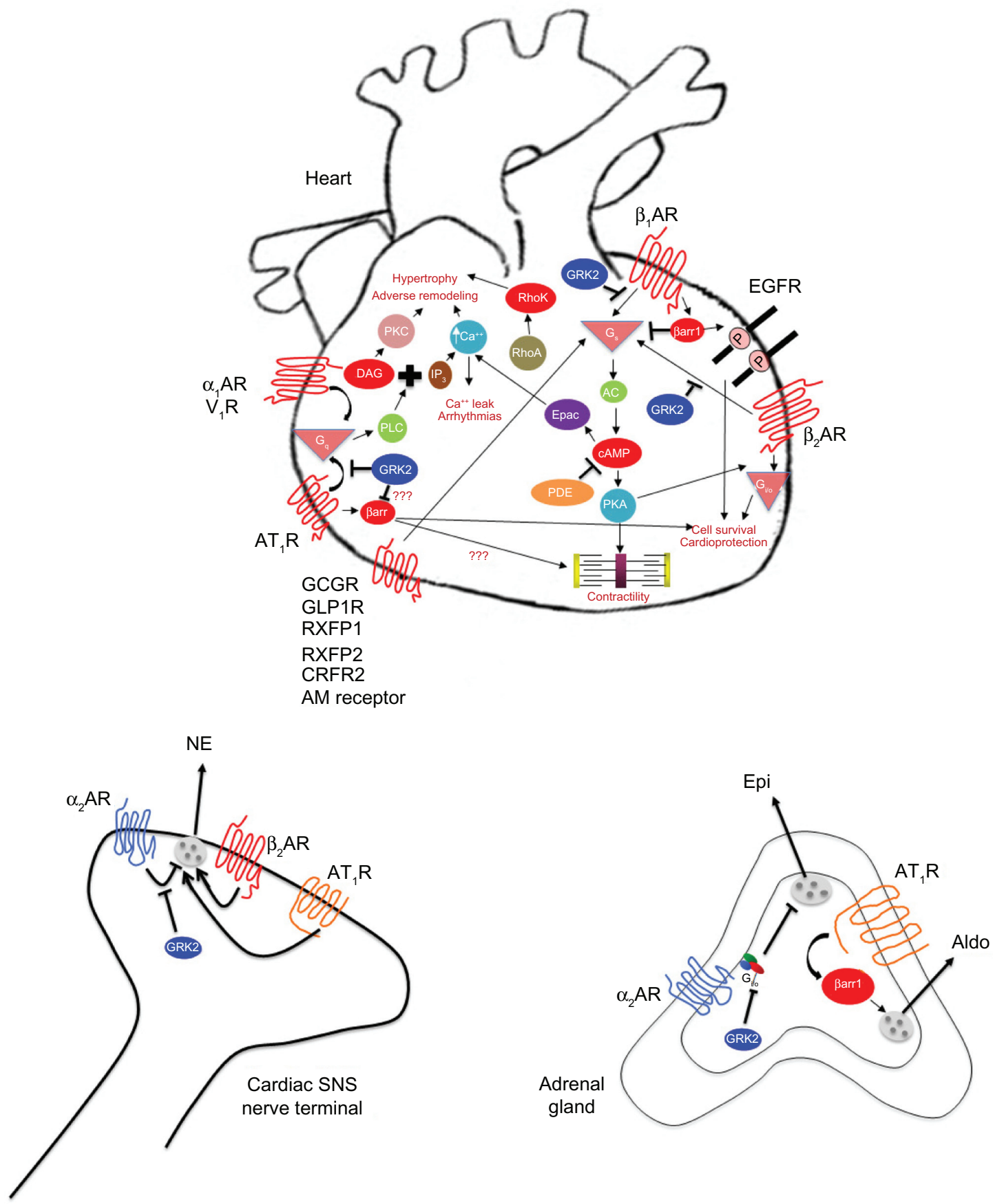

Figure I G protein-coupled receptors and their signaling pathways involved in heart failure pathophysiology.

Abbreviations: Aldo, aldosterone; AM, adrenomedullin; AR, adrenoceptor; $A T, R$, angiotensin II type I receptor; CRFR, corticotrophin-releasing factor receptor; DAG, 2-diacylglycerol; EGFR, epidermal growth factor receptor; Epi, epinephrine; GCGR, glucagon receptor; GLPIR, glucagon-like peptide-I receptor; GPCRs, G protein-coupled receptors; GRK, GPCR kinase; NE, norepinephrine; PDE, phosphodiesterase; RXFP, relaxin family peptide; SNS, sympathetic nervous system; ??!, indicates effect currently under

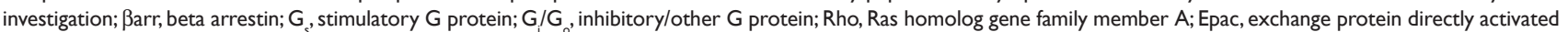
by cAMP;AC, adenylate cyclase; cAMP, cyclic adenosine monophosphate; PKA, protein kinase A; PKC, protein kinase C; PLC, phospholipase C; VIR, vasopressin receptor type I; RhoK, Rho-dependent kinase.

with the notion that chronic cardiac $\beta_{1} \mathrm{AR}$ activation is detrimental and pro-apoptotic in the heart (see below).

Importantly, the $\beta_{2} \mathrm{AR}$ also mediates the effects of catecholamines in the heart, but in a qualitatively different manner from $\beta_{1} \mathrm{AR}$, as it can also couple to the $\mathrm{AC}$ inhibitory $G$ protein $\left(G_{i}\right)$. In fact, this switching of $\beta_{2} A R$ signaling from $G_{s}$ to $G_{i}$ proteins is postulated to be induced by the phosphorylation of the $\beta_{2}$ AR by PKA (Figure 1). ${ }^{16}$ It is now generally accepted that in the heart, $\beta_{2} \mathrm{AR}$ signals and functions in a substantially different way than $\beta_{1} \mathrm{AR}:{ }^{18-20}$ whereas $\beta_{1} \mathrm{AR}$ activation enhances cardiomyocyte apoptosis, $\beta_{2} \mathrm{AR}$ exerts anti-apoptotic effects in the heart. ${ }^{18-21}$ This essential 
difference between the two receptor subtypes is ascribed to the signal of $\beta_{2}$ AR through $G_{i / o}$ proteins. ${ }^{19}$ This is the rationale behind the notion that promotion of $\mathrm{G}_{\mathrm{i} / \mathrm{o}}$ protein signaling might serve as a therapeutic strategy in HF in an effort to augment cardiac survival (anti-apoptotic, cardioprotective) (Figure 1 and Table 1). Nevertheless, studies using transgenic mice, $\beta_{2}$ AR-selective stimulation, and adenoviral-mediated $\beta_{2}$ AR overexpression have clearly demonstrated the protective effects of $\beta_{2}$ AR signaling in the myocardium, including improved cardiac function and decreased apoptosis. Conversely, hyperstimulation or overexpression of $\beta_{1} \mathrm{AR}$ has detrimental effects in the heart. ${ }^{21,22}$

Of note, the differences between the two predominant cardiac $\beta A R s$, ie, $\beta_{1} A R$ and $\beta_{2} A R$, in terms of their signaling properties, might take quite a different shape and have a much bigger bearing on pathophysiologic implications in the setting of human HF: for instance, and as discussed in more detail in subsequent sections, $\beta_{1} \mathrm{AR}$ is selectively downregulated (ie, functional receptor number reduced) in human $\mathrm{HF}$, thus shifting the above-mentioned stoichiometry of $\beta_{1} \mathrm{AR}: \beta_{2} \mathrm{AR}$ toward 50:50 in the failing heart from $\sim 75 \%$ : 20\% in the normal, healthy heart. ${ }^{23,24}$ However, $\beta_{2} \mathrm{AR}$ is also nonfunctional and does not signal properly in the failing heart. ${ }^{23,24}$ In addition, emerging evidence suggests that $\beta_{2} \mathrm{AR}$ signaling in the failing heart is quite different from that in the normal heart, ie, is more diffuse and noncompartmentalized and resembles more the pro-apoptotic "diffuse" cAMP signaling pattern of the $\beta_{1}$ AR. ${ }^{25}$ Therefore, this stoichiometric shift in favor of the supposedly "good" $\beta_{2} A R$ in HF appears unable to help the heart improve its structure and function.

Chronic $\beta$-blocker (ie, $\beta$ AR antagonist) therapy reverses $\mathrm{LV}$ remodeling in $\mathrm{HF}$, reduces risk of hospitalization, improves survival, reduces risk of arrhythmias (sudden cardiac death), improves coronary blood flow to the heart (relieves angina), and protects the heart against cardiotoxic overstimulation by the catecholamines (NE and Epi). ${ }^{9}$ All of these effects result in a decrease in the oxygen/energy and metabolic demands of the heart (cardiac workload is decreased) and in an increase in its oxygen/energy supply, thereby improving, in the long run, LV function and performance. Various molecular mechanisms underlying these effects have been postulated: 1) direct antagonism of catecholaminergic cardiotoxic effects; 2) cardiac $\beta A R$ upregulation and restoration of their signaling and function (ie, increase in adrenergic and inotropic reserves of the heart), which is needed in situations where the heart needs to work and sustain systemic circulation (eg, in acute stress or in acute HF episodes), ${ }^{26} 3$ ) suppression of the elevated cardiotoxic, adverse remodeling-promoting, and pro-apoptotic neurohormonal systems (RAAS, endothelin); 4) coronary blood flow enhancement (as a result of diastolic prolongation); and 5) restoration of the reflex controls on the heart and the circulation. ${ }^{27}$ Given that $\beta_{2}$ AR signaling, unlike $\beta_{1}$ AR signaling, might be cardioprotective in $\mathrm{HF}$, novel $\beta_{1} \mathrm{AR}-$ selective $\beta$-blockers (ie, like metoprolol) or combinations of a $\beta$-blocker with a $\beta_{2}$ AR-selective agonist (eg, clenbuterol) might be preferable for HF therapy (Table 1 ), ${ }^{28}$ although carvedilol, a very successful and efficacious $\beta$-blocker in HF therapy, lacks $\beta$ AR subtype selectivity. ${ }^{29}$

\section{$\alpha_{1} A R$ signaling targets for HF therapy}

The human heart also expresses $\alpha_{1}$ ARs, albeit at much lower levels than $\beta$ ARs $(~ 20 \%$ of total $\beta$ ARs $) .{ }^{30}$ Their role in cardiac physiology is still a matter of debate, contrary to their well established effects in regulation of blood flow by inducing constriction in the smooth muscle wall of major arteries (eg, aorta, pulmonary arteries, mesenteric vessels, coronary arteries, etc). ${ }^{31}$ The $\alpha_{1}$ ARs couple to the $\mathrm{G}_{\mathrm{q} / 11}$ family of heterotrimeric $\mathrm{G}$ proteins, thereby activating phospholipase $\mathrm{C}$ (PLC)- $\beta$. PLC $\beta$ generates the second messengers, inositol $[1,4,5]$-trisphosphate $\left(\mathrm{IP}_{3}\right)$ and 2-diacylglycerol (DAG) from the cell membrane component phospholipid phosphatidylinositol $(4,5)$-bisphosphate $\left(\mathrm{PIP}_{2}\right)$. IP 3 binds specific receptors in the sarcoplasmic reticulum (SR) membrane, which cause release of $\mathrm{Ca}^{2+}$ from intracellular stores, whereas DAG activates protein kinase $\mathrm{C}$ (PKC) (Figure 1). ${ }^{9}$ The end result is raised intracellular $\left[\mathrm{Ca}^{2+}\right]$, which leads to contraction in vascular smooth muscle (vasoconstriction) and to activation of hypertrophic programs in the heart (Figure 1). ${ }^{15}$ $\alpha_{1}$ ARs in HF may function in a compensatory fashion to maintain cardiac inotropy, but their involvement in cardiac pathophysiology appears limited to situations of cardiac hypertrophy that ultimately lead to $\mathrm{HF}^{32}$ For instance, in the presence of pressure overload, cardiac $\alpha_{1 \mathrm{~A}}$ ARs get activated and promote cardiomyocyte survival (ie, block apoptosis), protecting against adverse remodeling and decompensation to HF. ${ }^{33,34}$ Thus, cardiac $\alpha_{1}$ AR antagonism, as well as inhibition of some cardiac $\alpha_{1}$ AR signaling components, eg, $\mathrm{G}_{\mathrm{q}}$ proteins or PKC ( $\mathrm{PKC} \beta_{2}$, for instance), ${ }^{35,36}$ have been pursued as HF therapeutic modalities (Figure 1 and Table 1), but the jury is still out with regards to their effectiveness.

\section{$\alpha_{2} A R$ signaling targets for HF therapy}

Centrally located $\alpha_{2}$ ARs reduce SNS outflow (presynaptic inhibitory autoreceptors) and thus lower systemic blood 
Table I Potential G protein-coupled receptor signaling targets for drug development in heart failure

\begin{tabular}{|c|c|c|c|c|}
\hline Target/modality & $\begin{array}{l}\text { Representative } \\
\text { agents(s) }\end{array}$ & $\begin{array}{l}\text { HF type to be } \\
\text { treated }\end{array}$ & $\begin{array}{l}\text { Potential desirable effect(s) } \\
\text { in HF }\end{array}$ & Notes \\
\hline $\begin{array}{l}\beta_{2} A R \text { stimulation } \\
\text { (with concurrent } \\
\beta_{1} A R \text { inhibition) }\end{array}$ & Clenbuterol & Chronic HF & $\begin{array}{l}\text { Cardioprotection } \\
\uparrow \text { Survival }\end{array}$ & $\begin{array}{l}\text { Compatible with asthma, T2DM, and } \\
\text { therapies of other diseases }\end{array}$ \\
\hline $\begin{array}{l}\alpha_{2} \mathrm{AR} \text { agonism/ } \\
\text { sympatholysis }\end{array}$ & $\begin{array}{l}\text { Clonidine, moxonidine, } \\
\text { bucindolol }\end{array}$ & Chronic HF & $\begin{array}{l}\text { Cardioprotection } \\
\uparrow \text { Survival } \\
\downarrow \text { Adverse remodeling }\end{array}$ & $\begin{array}{l}\alpha_{2} A R \text { desensitization in chronic HF and } \\
\text { incompatibility of excessive sympatholysis } \\
\text { with life are potential problems }\end{array}$ \\
\hline $\begin{array}{l}A T_{1} R \text {-dependent } G_{q} \\
\text { protein signaling } \\
\text { antagonism }\end{array}$ & ARBs (eg, losartan) & Chronic HF & $\begin{array}{l}\text { Cardioprotection } \\
\uparrow \text { Survival } \\
\downarrow \text { Adverse remodeling } \\
\downarrow \text { Hypertrophy }\end{array}$ & $\begin{array}{l}\downarrow \text { SNS tone additional advantage in HF } \\
\text { treatment }\end{array}$ \\
\hline $\mathrm{G}_{\mathrm{i} / \mathrm{o}}$ protein stimulation & None known as yet & Chronic HF & $\begin{array}{l}\text { Cardioprotection } \\
\uparrow \text { Survival }\end{array}$ & $\begin{array}{l}\downarrow \text { contractility, CO (acutely) and } \\
\text { bradycardia are disadvantages }\end{array}$ \\
\hline $\begin{array}{l}\mathrm{G}_{\mathrm{q}} \text { protein/PKC } \beta 2 \\
\text { inhibition }\end{array}$ & $\begin{array}{l}\mathrm{G}_{\mathrm{ql}} \\
\text { ruboxistaurin, } \\
\text { LY379196 }\end{array}$ & Chronic HF & $\begin{array}{l}\downarrow \text { Adverse remodeling } \\
\downarrow \text { Hypertrophy }\end{array}$ & \\
\hline $\begin{array}{l}\text { Endothelin receptor } \\
\text { antagonism }\end{array}$ & Bosentan, ambrisentan & $\begin{array}{l}\text { Right atrial/ } \\
\text { ventricular } \mathrm{HF}\end{array}$ & $\begin{array}{l}\text { Improved pulmonary arterial } \\
\text { pressure }\end{array}$ & $\begin{array}{l}\downarrow \text { PAH } \\
\downarrow \text { SNS tone (?) potential advantage }\end{array}$ \\
\hline AIR (partial) agonism & Capadenoson & Chronic HF & $\begin{array}{l}\text { Cardioprotection } \\
\uparrow \text { Survival }\end{array}$ & $\begin{array}{l}\downarrow \text { arrhythmias, benefit in ischemic } \\
\text { preconditioning are potential advantages; } \\
\text { bradycardia is a disadvantage (although is } \\
\text { less with partial agonism) }\end{array}$ \\
\hline $\begin{array}{l}\text { Adrenomedullin } \\
\text { receptor agonism }\end{array}$ & $\begin{array}{l}\text { Adrenomedullin, } \\
\text { intermedin }\end{array}$ & $\begin{array}{l}\text { Acute and } \\
\text { chronic HF }\end{array}$ & $\begin{array}{l}\uparrow \text { Contractility, } \mathrm{CO} \\
\text { Improved circulation parameters } \\
\text { (BP, natriuresis) }\end{array}$ & Benefit in chronic HF unknown \\
\hline $\begin{array}{l}\text { Relaxin receptor } \\
\text { agonism }\end{array}$ & Serelaxin (Rxn-2) & $\mathrm{ADHF}$ & $\begin{array}{l}\uparrow \text { Contractility, } \mathrm{CO} \\
\text { Improved circulation parameters } \\
\text { (BP, natriuresis) }\end{array}$ & $\begin{array}{l}\text { Serelaxin currently in clinical trials for } \\
\text { ADHF (RELAX-AHF) }\end{array}$ \\
\hline CRFR2 agonism & $\begin{array}{l}\text { Stresscopin, } \\
\text { Ucn-I, } \\
\text { Ucn-2 }\end{array}$ & $\mathrm{ADHF}$ & $\begin{array}{l}\uparrow \text { Contractility, } \mathrm{CO} \\
\text { Improved circulation parameters } \\
\text { (BP, natriuresis, vasodilation) }\end{array}$ & Benefit in chronic HF unknown \\
\hline $\begin{array}{l}\text { Vasopressin receptor } \\
\text { antagonism }\end{array}$ & $\begin{array}{l}\text { Tolvaptan } \\
\left(\mathrm{V}_{2} \mathrm{R} \text {-selective }\right)\end{array}$ & Chronic HF & $\begin{array}{l}\text { Improved circulation parameters } \\
\text { (BP, natriuresis, diuresis, } \\
\text { vasodilation), } \\
\downarrow \text { Hyponatremia } \\
\downarrow \text { Cardiac hypertrophy (?) }\end{array}$ & $\begin{array}{l}\text { Direct cardiac effects unknown, } \\
\text { Tolvaptan approved in several countries } \\
\text { for HF but not in the USA }\end{array}$ \\
\hline $\begin{array}{l}\text { Glucagon peptide } \\
\text { receptor agonism }\end{array}$ & $\begin{array}{l}\text { Glucagon, exenatide } \\
\text { (GLPIR peptide agonist) }\end{array}$ & $\begin{array}{l}\text { Chronic HF, } \\
\text { diabetic } \\
\text { cardiomyopathy }\end{array}$ & $\begin{array}{l}\uparrow \text { Contractility, CO } \\
\text { Cardioprotection } \\
\uparrow \text { Survival } \\
\uparrow \text { Myocyte proliferation }\end{array}$ & $\begin{array}{l}\text { Glucagon is used to acutely raise } \mathrm{CO} \text { in } \\
\text { ADHF if patient is on } \beta \text {-blockers, } \\
\text { Potential advantage in HF complicated } \\
\text { with DM }\end{array}$ \\
\hline RhoA/RhoK inhibition & Fasudil (RhoK inhibitor) & Chronic HF & $\downarrow$ Adverse remodeling after MI & \\
\hline Epac inhibition & None known as yet & Chronic HF & $\begin{array}{l}\text { Cardioprotection (?) } \\
\downarrow \text { Arrhythmias (?) }\end{array}$ & \\
\hline GRK2 blockade & Paroxetine, $\beta$ ARKct & $\begin{array}{l}\text { Acute and } \\
\text { chronic HF }\end{array}$ & $\begin{array}{l}\uparrow \text { Contractility, CO } \\
\text { Cardioprotection } \\
\uparrow \text { Survival } \\
\downarrow \text { Cardiac hypertrophy } \\
\downarrow \text { SNS (and RAAS) tones }\end{array}$ & $\begin{array}{l}\beta A R K c t \text { is entering clinical trials for } \\
\text { chronic HF soon }\end{array}$ \\
\hline $\begin{array}{l}\text { Barr2 stimulation } \\
\text { (with concurrent } \\
\text { Barrl inhibition) }\end{array}$ & $\begin{array}{l}\text { None known as yet, } \\
\text { Barrlct }\end{array}$ & $\begin{array}{l}\text { Acute and } \\
\text { chronic HF }\end{array}$ & $\begin{array}{l}\uparrow \text { Contractility, CO } \\
\text { Cardioprotection } \\
\uparrow \text { Survival } \\
\downarrow \text { SNS (and RAAS) tones }\end{array}$ & $\begin{array}{l}\text { Exact role(s) of } \beta \text { arr I versus } \beta \text { arr } 2 \text { in } \\
\text { the heart still await delineation, TRV } 027 \\
\text { (AT, R ßarr-biased agonist peptide) } \\
\text { currently in development for ADHF }\end{array}$ \\
\hline
\end{tabular}

Abbreviations: AIR, adenosine type I receptor; ADHF, acute decompensated HF; AR, adrenoceptor; ARB, angiotensin receptor blocker; AT, R, angiotensin II type I receptors; BP, blood pressure; cAMP, cyclic adenosine monophosphate; CO, cardiac output; CRFR2, corticotrophin-releasing factor receptor type 2; DM, diabetes mellitus; Epac, exchange protein directly activated by cAMP; GPCR, G protein-coupled receptor; $\mathrm{G}_{q}, \mathrm{G}_{q}$ protein inhibitor peptide; GRK, GPCR kinase; HF, heart failure; MI, myocardial infarction; PAH, pulmonary arterial hypertension; PKC, protein kinase C; RAAS, renin-angiotensin-aldosterone system; RELAX-AHF, Relaxin in Acute Heart Failure clinical trial; RhoA/K, ras homolog gene family member A/Rho-dependent kinase; Rxn-2, relaxin-2; SNS, sympathetic nervous system; T2DM, type 2 diabetes mellitus; Ucn, urocortin; $\mathrm{V}_{2} \mathrm{R}$, vasopressin receptor type 2; ßarr, beta arrestin; ?, indicates effect currently under investigation; ct, C-terminal fragment; G/G, inhibitory/other G protein; GLPIR, glucagon-like peptide-I receptor; $\beta$ ARK, beta-adrenergic receptor kinase. 
pressure..$^{37,38}$ The release of NE from cardiac sympathetic nerve terminals is controlled by both presynaptic $\alpha_{2 \mathrm{~A}}$ - and $\alpha_{2 \mathrm{C}} \mathrm{ARs},{ }^{39,40}$ and secretion of Epi (mainly) and NE from the adrenal medulla is also controlled (ie, inhibited) by $\alpha_{2 \mathrm{C}} \mathrm{ARs}$ present in chromaffin cell membranes (Figure 1). ${ }^{41,42}$ Genetic deletion of both $\alpha_{2 \mathrm{~A}}$ - and $\alpha_{2 \mathrm{C}} \mathrm{AR}$ subtypes leads to cardiac hypertrophy and HF due to chronically enhanced cardiac NE release, as well as enhanced NE and Epi secretion from the adrenal medulla. ${ }^{40-42}$ In addition, the human $\alpha_{2 \mathrm{C}} \mathrm{AR}$ Del322-325 genetic variant that displays impaired signaling and sympatho-inhibitory function is associated with increased risk of HF in homozygous African-American carriers, especially when co-carried with the hyperfunctional cardiac $\beta_{1} \mathrm{AR}$ Arg389 genetic variant, with the most probable mechanism being attenuated auto-inhibitory feedback of, and thus enhanced NE release from, the cardiac sympathetic nerves. ${ }^{43}$ In fact, even in healthy humans, the $\alpha_{2 \mathrm{C}} \mathrm{AR}$ Del322-325 variant is associated with increased sympathetic nervous and adrenomedullary hormonal activities, during both supine rest and pharmacologically evoked catecholamine release ${ }^{44}$ Thus, presynaptic inhibitory $\alpha_{2}$-adrenergic autoreceptors crucially regulate SNS cardiac nerve activity and NE release into the heart, and any dysfunction of these receptors, either due to genetic polymorphisms or enhanced desensitization/downregulation (see GRK targets for HF therapy), translate into increased morbidity and mortality in chronic HF (Figure 1). Perhaps the crucial role of presynaptic $\alpha_{2}$ ARs in regulating NE release from cardiac SNS nerves stems from the fact that they are the only presynaptic ARs that can inhibit NE release; ${ }^{9}$ presynaptic $\beta$ ARs (of the $\beta_{2}$ AR subtype, mainly) are facilitatory autoreceptors enhancing NE release at sympathetic nerve terminals, ${ }^{9}$ a phenomenon whose inhibition may contribute to the therapeutic benefit of $\beta$-blockers in HF (see $\beta$ AR signaling targets for HF therapy) (Figure 1).

One of the hallmark abnormalities of chronic HF, contributing significantly to its morbidity and mortality, is chronically elevated SNS activity/outflow, as reflected by enhanced NE release in the heart (increased NE spillover) and enhanced adrenal catecholamine secretion leading to elevated circulating catecholamines. ${ }^{45-47}$ Initially an adaptive mechanism aiming to compensate decreased contractility following cardiac insult, it becomes progressively maladaptive, contributing to HF establishment and progression and to its morbidity and mortality. ${ }^{48,49}$ Based on this, sympatholysis (ie, reduction of SNS outflow and of circulating NE and Epi) is among the desirable goals of chronic HF therapy, and $\alpha_{2} \mathrm{AR}$ agonism has been employed in HF clinical trials as one such strategy (Figure 1 and Table 1). However, one such drug, moxonidine, failed to provide any survival or hemodynamic benefits in its clinical trial (Sustained Release Moxonidine for Congestive Heart Failure [MOXCON] $),{ }^{50}$ an unexpected and unfortunate outcome attributed (somewhat paradoxically) to excessive, incompatible with life sympatho-inhibition caused by the drug (Table 1). Unfortunately, this misfortune essentially ended further interest by industry in developing sympatholytic strategies for chronic HF, although bucindolol, a $\beta$-blocker with strong sympatholytic properties, is currently being promoted for chronic HF treatment based (in part) also on its SNS activitylowering effects. ${ }^{51}$ Of note, chronic HF is also accompanied by enhanced $\alpha_{2} \mathrm{AR}$ desensitization and downregulation (see GRK targets for HF therapy and Table 1), ${ }^{52}$ which might be another reason that moxonidine failed in its clinical trials for HF therapy.

\section{$A T_{1} R$ signaling targets for HF therapy}

Landmark studies have shown that antagonism of RAAS provides HF patients with a substantial symptomatic and survival advantage..$^{53,54}$ These observations are supported by studies unequivocally showing activation of the RAAS in both clinical and experimental HF. ${ }^{55}$ Furthermore, the pivotal role of angiotensin II, acting through $\mathrm{AT}_{1} \mathrm{Rs}$, in the process of cardiac adverse remodeling has been clearly documented in both clinical and experimental HF models. ${ }^{56}$ Thus, both angiotensin-converting enzyme (ACE) inhibitors, which inhibit synthesis of angiotensin II, and $\mathrm{AT}_{1} \mathrm{R}$ antagonists (the so-called "angiotensin receptor blockers" [ARBs]) (Table 1) ameliorate HF-associated LV adverse remodeling, such as fibrosis, hypertrophy, dilatation, myocardial stiffness, and oxidative stress, particularly after myocardial infarction, and RAAS antagonism is the cornerstone of all pharmacotherapeutic regimens currently employed in HF treatment. ${ }^{57}$ Further adding to the importance of RAAS inhibition for HF therapy, antagonism of aldosterone, which is produced by the adrenal cortex (and possibly also in the heart per se) in response to angiotensin II activation of $\mathrm{AT}_{1} \mathrm{Rs}$ and is the last hormone activated in the RAAS hormonal axis, has recently emerged as a very effective therapeutic strategy for advanced-stage HF, promoting patient survival and ameliorating $\mathrm{LV}$ adverse remodeling (Figure 1) ${ }^{58} \mathrm{AT}_{1} \mathrm{R}$ is a classic $\mathrm{G}_{\mathrm{q} / 11}$-coupled receptor, ie, it signals through the very same pathway as do $\alpha_{1}$ ARs (see $\alpha_{1}$ AR signaling targets for $\mathrm{HF}$ therapy) (Figure 1), although it can also couple to $G_{i / o}$ and $\mathrm{G}_{\mathrm{s}}$ proteins in certain cell types. ${ }^{8}$ In addition, it also signals via $\beta$ arrestins ( $\beta$ arrs), independently of $G$ proteins (see $\beta$ arr targets for HF therapy). ${ }^{8}$ Finally, in the central nervous system (CNS), the $\mathrm{AT}_{1} \mathrm{R}$ can elevate SNS activity/outflow, which also contributes to the adverse hemodynamic and LV remodeling 
responses to myocardial infarction that angiotensin II activation of this receptor elicits. ${ }^{9}$ Thus, part of the benefit of RAAS inhibitors (and of $\mathrm{AT}_{1} \mathrm{R}$ antagonists in particular) in HF might also derive from centrally mediated suppression of SNS activity (Figure 1 and Table 1).

\section{Targets for HF therapy in signaling from other GPCRs Endothelin receptors}

Unlike blockade of the SNS and RAAS, which have been successful in HF therapy, strategies targeting the endothelin system have largely failed. ${ }^{1}$ Endothelin is another cardiotoxic hormone, the plasma concentrations of which are considerably increased in patients with HF and correlate with disease severity. ${ }^{59}$ Additionally, endothelin is the most potent endogenous vasoconstrictor substance produced in the body (much more potent than angiotensin II). ${ }^{59}$ Therefore, development of endothelin receptor antagonists for HF therapy made perfect sense on paper, but, although the hemodynamic profile of various endothelin receptor inhibitors has been favorable and these drugs have proven to be of significant therapeutic value for pulmonary arterial hypertension (PAH) and might also be of value in coronary artery disease (CAD), they have not provided any substantial benefit for HF patients in terms of survival or disease progression. ${ }^{59,60}$ This might indicate that endothelin receptor signaling has only a minimal impact on cardiac function and certainly negligible compared with the impact of adrenergic or angiotensin II receptor signaling in the heart. The only HF indication for which endothelin receptor antagonists might hold promise right now appears to be right atrial/ventricular $\mathrm{HF}$, given the benefits they provide in PAH (Table 1).

\section{Adenosine receptors}

Adenosine is a purine nucleoside that exerts a variety of physiological actions by binding to four adenosine cell surface GPCR subtypes, namely A1, A2a, A2b, and A3. The cardioprotective effects of adenosine have been extensively studied and are primarily mediated by activation of the A1-receptor (A1R) subtype in ischemic preconditioning. ${ }^{61}$ However, activation of A1R, which primarily couples to (inhibitory or other) $\mathrm{G}_{\mathrm{i} / \mathrm{o}}$ proteins, also slows $\mathrm{HR}$, which is therapeutically exploited in treatment of certain supraventricular arrhythmias, but, in the context of chronic HF, it might constitute an undesirable effect, as it can lead to bradycardias and atrioventricular blocks. ${ }^{61}$ A partial A1R agonist, capadenoson, ${ }^{62}$ was very recently shown to improve LV function and prevent progressive cardiac adverse remodeling in a canine chronic HF model. ${ }^{63}$ Importantly, improvement of
LV systolic function seemed to occur early after treatment initiation with capadenoson, and, since the compound is not a full agonist at the A1R, it appears devoid of the HR-lowering complications with which full A1R agonism is hampered. ${ }^{63}$ Although the precise signaling mechanism(s) that mediate these beneficial effects of partial A1R agonism in chronic HF remain to be worked out, this study strongly indicates that A1R-selective (partial) agonists might have a place in the chronic HF drug armamentarium in the future (Table 1).

\section{Adrenomedullin receptor}

Adrenomedullin is a peptide hormone released from multiple tissue types, including the kidneys and the adrenal medulla, in response to pressure and volume overloads, and its plasma levels have been shown to be elevated in acute decompensated HF. ${ }^{64}$ In chronic HF, its levels appear to be independently predictive of 2 year mortality, especially in non-ischemic and in New York Heart Association (NYHA) class II or lower HF. ${ }^{64}$ Its receptor is also a GPCR, albeit an unusual one: the receptor protein is encoded by the calcitonin receptor-like receptor (CRLR) gene, but, on its own, it is not functional. The receptor protein has to structurally couple to one of the receptor activity-modifying proteins (RAMPs) in order to become functional and capable of signaling. ${ }^{65}$ The adrenomedullin receptor thus consists of the CRLR bound to RAMP2 (or RAMP3) and primarily couples to the $\mathrm{G}$ protein $\mathrm{G}_{\mathrm{s}}$, ie, activates, similarly to the $\beta A R s$, the classic AC-cAMP-PKA signaling pathway, which, in the cardiac myocyte, leads to positive inotropy (increased contractility) (Figure 1). ${ }^{65}$ Therefore, adrenomedullin and its analogs exert potent positive inotropic effects in the heart, which, coupled with their other beneficial effects on the circulation, such as hypotension and natriuresis, ${ }^{66}$ make adrenomedullin receptor agonists (adrenomedullin non-peptide analogs, for instance) attractive possibilities for future HF drug development (Table 1). What's more, these drugs might prove useful for both acute and chronic HF treatments.

\section{Relaxin receptors}

The relaxins are a multi-member peptide hormone family comprising several relaxin-like and insulin-like peptides. ${ }^{67}$ They are primarily involved in functional regulation of the reproductive and neuroendocrine systems, but they are also present in the brain and in the cardiovascular system, where relaxin-1 and -2 exert potent vasoactive (vasodilatory) effects. ${ }^{67}$ Their cellular effects are mediated by four different types of relaxin family peptide (RXFP) receptors, which are all GPCRs. RXFP1 and RXFP2 receptors primarily couple to the $\mathrm{G}_{\mathrm{s}}$ protein-AC-cAMP-PKA signaling pathway, which 
leads to positive inotropy in the heart and vasodilatation in vascular smooth muscle (Figure 1) ${ }^{67}$ The RXFP1 receptor has also been shown to activate the phosphatidylinositol 3-kinase (PI3K) and extracellular signal-regulated kinase (ERK) signaling pathways. ${ }^{67}$ Given that RXFP1 and RXFP2 receptors, which are both activated by relaxin-2, can lead to positive inotropy in the myocardium, ${ }^{67}$ recombinant relaxin peptides and peptide analogs are currently pursued for $\mathrm{HF}$ drug development, and especially for acute decompensated HF (Table 1). One such agent, recombinant human relaxin-2 or serelaxin, is currently in clinical trials by Novartis for acute HF treatment, and the results have so far been more than encouraging. ${ }^{68}$ Thus, development of relaxin peptide analogs and, specifically, of RXFP1 or RXFP2 receptor peptide or non-peptide agonists for acute HF is another area of HF drug development research that currently holds great promise, even though the chances of these agents also proving useful for chronic HF are low (Table 1).

\section{Corticotrophin-releasing factor receptors} Corticotrophin-releasing factor (CRF) receptors (CRFRs) are GPCRs for the CRF family of peptide hormones, which includes urotensin-1, urocortins (Ucns), and CRF (or corticotrophin-releasing hormone [CRH]) itself, of course. ${ }^{69}$ CRFR type 2 (CRFR2) is abundantly expressed in the human heart and primarily couples to $\mathrm{G}_{\mathrm{s}}$ proteins, thereby activating the AC-cAMP-PKA (ie, the positive inotropic) signaling pathway of the cardiomyocytes (Figure 1). ${ }^{69}$ This means that CRFR2 agonism can have cardiostimulatory effects and, indeed, in sheep HF, CRFR2 activation by Ucn 1 induces sustained reductions in cardiac preload and afterload, improvements in cardiac output, and inhibition of a variety of cardiotoxic neurohormonal systems (eg, RAAS, endothelin, vasopressin, etc). ${ }^{70}$ Antagonism of this receptor produces the mirror opposite effects in the same animals. ${ }^{70}$ On the other hand, in human HF, CRFR2 activation by Ucn2 or stresscopin (a CRF-like peptide that selectively activates CRFR2) induces increases in cardiac output and LV ejection fraction, along with a fall in systemic vascular resistance. ${ }^{71,72}$ Thus, similarly to the adrenomedullin and relaxin receptors above, Ucn-dependent CRFR2 activation produces positive inotropic, vasodilatory, and diuretic effects simultaneously, thereby making CRFR2 agonism another possible avenue for future HF drug development (Table 1).

\section{Vasopressin receptors}

Vasopressin is another very potent vasoactive peptide hormone that exerts its cellular actions via GPCRs (three different vasopressin receptor types: $\left.V_{1} R, V_{2} R, V_{3} R\right) .{ }^{73}$ The human cardiac myocyte expresses (albeit to a limited extent) $\mathrm{V}_{1} \mathrm{R}$, which is a $\mathrm{G}_{\mathrm{q} / 11}$ protein-coupled receptor, ie, activates the PLC $\beta-\mathrm{IP}_{3}-\mathrm{DAG}-\mathrm{PKC}$ signaling pathway, similarly to the $\alpha_{1}$ ARs (see $\alpha_{1}$ AR signaling targets for HF therapy). ${ }^{73}$ This signaling pathway leads to vasoconstriction in vascular smooth muscle cells and to hypertrophy in the myocardium, again similarly to the $\alpha_{1}$ ARs (Figure 1). Thus, vasopressin receptor antagonism poses as a possible therapeutic strategy in HF to combat cardiac hypertrophy, high blood pressure and systemic vascular resistance, overactivation of other cardiotoxic neurohormonal systems (eg, RAAS, SNS), and, of course, to reduce volume overload of the heart, along with its accompanying water and electrolyte abnormalities, which stem from the excessive $\mathrm{V}_{2} \mathrm{R}$-dependent anti-diuresis in the kidneys that causes hyponatremia. ${ }^{74,75}$ Nevertheless, the main indication for vasopressin receptor antagonist drugs currently is hyponatremia (along with some other renal indications), and only in very few countries (eg, Japan but not in the USA) are they currently approved for congestive HF (Table 1). ${ }^{76}$ Pretty much like $\alpha_{1} \mathrm{AR}$ and endothelin receptor antagonism, cardiac $\mathrm{V}_{1} \mathrm{R}$ antagonism, as well as antagonism of vasopressin receptors in general, clearly warrants further investigation before it can be considered a legitimate therapeutic strategy for HF.

\section{Glucagon peptide hormone receptors}

Glucagon receptor (GCGR) and glucagon-like peptide (GLP)-1 receptor (GLP1R) are class B GPCRs mediating some of the cardiovascular effects of glucagon and GLP1, respectively, both members of the glucagon family of peptide hormones. ${ }^{77}$ GCGR is a $\mathrm{G}_{\mathrm{s}}$ protein-coupled receptor and is present in cardiac myocyte membranes, where it can activate the positive inotropic AC-cAMP-PKA signaling pathway, pretty much like the $\beta_{1} \mathrm{AR}$ does (Figure 1). ${ }^{77}$ This constitutes the molecular basis for the clinical use of glucagon to acutely raise cardiac output in acute decompensated HF patients who are on $\beta$-blockers, ${ }^{77}$ a situation in which use of adrenergic positive inotropes (eg, dobutamine, dopamine) would be ineffective (Table 1). Glucagon receptor agonism for chronic HF has not been studied but is probably not recommended, given that it is, in essence, a positive inotropic therapy that raises workload and oxygen and metabolic demands of the heart.

The GLP1 $\mathrm{R}$ is also expressed in the heart, where it seems to mediate some of the beneficial cardiac effects of GLP1, such as inhibition of apoptosis, myocyte proliferation, and even positive inotropy. ${ }^{78,79}$ The signaling pathways initiated by GLP1R in the heart underlying these GLP1 effects are 
not entirely clear, but probably involve activation of the PI3K-Akt and the ERK1/2 signaling cascades (see Relaxin receptors), pathways known to result in cell survival and proliferation. ${ }^{78,79}$ Given these beneficial effects of GLP1R in the heart, GLP1 analogs have been tried as potential therapies in a number of experimental HF studies, including some with concurrent diabetes mellitus but also some independent of diabetic complications, and the results are overall promising. ${ }^{78,79}$ Thus, GLP1R agonism represents another potential avenue for future HF drug development, especially for those types of HF that are of diabetic etiology or are complicated by diabetes (Table 1).

\section{G protein targets for HF therapy}

With regards to heterotrimeric $\mathrm{G}$ proteins as potential targets for HF therapy, the reader is referred to the preceding sections of this article (specifically, the sections on ARs). In addition to the heterotrimeric G proteins, small (or Ras-like) G proteins also exist and provide an important link between the cell surface and intracellular signaling pathways. ${ }^{80}$ Among these, the small G protein "Ras homolog gene family member A" (RhoA) activates a protein kinase, the Rho kinase, which can drive the cardiac hypertrophic process (Figure 1) ${ }^{80}$ Inhibition of Rho kinase with the drug fasudil has been shown to reverse LV remodeling in experimental myocardial infarction, thus posing Rho kinase (or perhaps even RhoA itself) as a novel molecular target for HF therapy (Figure 1 and Table 1). ${ }^{81,82}$

Moreover, the second messenger cAMP can activate, in addition to PKA (see $\beta A R$ signaling targets for HF therapy), another effector in the cardiac myocyte, the "Exchange protein directly activated by cAMP" (Epac) (Figure 1). ${ }^{83}$ Epac was initially discovered as a cAMP-dependent and PKAindependent guanine nucleotide exchange factor (GEF) for the small G protein Rap1 (ie, Rap1 activator) but it is now known to be a multi-purpose adapter protein mediating a plethora of protein-protein interactions in the cell. ${ }^{83}$ Epac2 was recently shown to mediate $\beta_{1} \mathrm{AR}$-dependent $\mathrm{SR} \mathrm{Ca}^{2+}$ leak and arrhythmias in the heart, upon its activation by cAMP generated by cardiac $\beta_{1}$ AR stimulation. ${ }^{84}$ This suggests that Epac inhibition might be of therapeutic value for cardiac arrhythmias and potentially also for HF, but further studies are needed to delineate the precise role(s) of Epac in the heart and in HF (Figure 1 and Table 1).

\section{GRK targets for HF therapy}

The majority of GPCRs are subject to agonistpromoted (homologous) desensitization and downregulation, a regulatory process that diminishes receptor response to continuous or repeated agonist stimulation. ${ }^{85,86}$ At the molecular level, this process is initiated by receptor phosphorylation by a family of kinases, termed GPCR kinases (GRKs), followed by binding of $\beta$ arrs to the GRK-phosphorylated receptor. The $\beta$ arrs then uncouple the receptor from its cognate $\mathrm{G}$ proteins, sterically hinder its further binding to them (functional desensitization), and subsequently target the receptor for internalization. ${ }^{85,86}$ Across all mammalian species, GRK2 and GRK5 are the most physiologically important members of the GRK family because they are expressed ubiquitously and regulate the vast majority of GPCRs. They are particularly abundant in neuronal tissues and in the heart. ${ }^{87,88}$ The elevated SNS outflow and NE and Epi levels in chronic HF lead to chronically elevated stimulation of the cardiac $\beta$ AR system, which has detrimental repercussions for the failing heart. Extensive investigations over the past 3 decades have helped delineate the molecular alterations afflicting the cardiac $\beta$ AR system that occur during HF, and it is now well known that, in chronic human $\mathrm{HF}$, cardiomyocyte $\beta \mathrm{AR}$ signaling and function are significantly deranged and the adrenergic reserve of the heart is diminished. ${ }^{9,48}$ Cardiac $\beta$ AR dysfunction in human HF is characterized at the molecular level by selective reduction of $\beta_{1}$ AR density at the plasma membrane (downregulation) and by uncoupling of the remaining membrane $\beta_{1}$ ARs and $\beta_{2}$ ARs from $G$ proteins (functional desensitization). ${ }^{23,24}$ Importantly, myocardial levels and activities of GRK2 and GRK5 are elevated, both in humans and in animal models of HF. ${ }^{89,90}$ This GRK elevation possibly serves as a homeostatic protective mechanism aimed at defending the heart against excessive catecholaminergic toxicity. However, several studies soon refuted this assumption, demonstrating that GRK2 upregulation is detrimental for the heart and causes the functional uncoupling of $\beta$ ARs in vivo. ${ }^{91}$ This finding prompted investigations of the role GRK2 plays in cardiac function, which revealed that cardiac GRK2 is an absolutely critical regulator of cardiac $\beta$ AR-dependent contractility and function. Specifically, cardiomyocyte-restricted overexpression of GRK2 to the same level of upregulation found in human HF (ie, three- to four-fold) markedly attenuated $\beta A R$ signaling and contractile reserve, showing that GRK2 is the main culprit for the functional desensitization of cardiac $\beta$ ARs in HF (Figure 1). ${ }^{92}$ The proof for this was provided by studies of the in vivo inhibition of cardiomyocyte GRK2, which were enabled by the development of the $\beta$ ARKct (beta adrenergic receptor kinase $\mathrm{C}$-terminal fragment) mini-gene, which blocks cell membrane translocation and hence activation of GRK2, and its cardiomyocyte-specific expression in vivo in 
transgenic mice by virtue of the $\alpha \mathrm{MHC}$ (myosin heavy chain) gene promoter. ${ }^{90}$ Indeed, GRK2 inhibition in vivo in the heart with $\beta A R K c t$ (or its partial genetic deletion) enhances cardiac contractility both at baseline and after adrenergic stimulation, reverses the contractile and $\beta A R$ dysfunctions, and preserves or even augments cardiac function and survival in $\mathrm{HF} .{ }^{90} \mathrm{Of}$ note, the antidepressant paroxetine was recently shown to inhibit GRK2, thus providing a lead for the development of GRK2-specific small molecule inhibitors. ${ }^{93}$ In summary, elevated SNS activity in chronic HF causes enhanced GRK2mediated cardiac $\beta_{1}$ - and $\beta_{2} \mathrm{AR}$ desensitization and $\beta_{1} \mathrm{AR}$ downregulation, which leads to the progressive loss of the adrenergic and inotropic reserves of the heart, the hallmark molecular abnormality of this disease (Figure 1). ${ }^{94}$

Additionally, GRK2 expression and activity are also increased in the adrenal gland during HF. ${ }^{95}$ Specifically, our studies over the past few years have established that adrenal GRK2 upregulation is responsible for severe adrenal $\alpha_{2}$ AR dysfunction in chronic HF, which causes a loss of the sympatho-inhibitory function of these receptors in the adrenal gland, and catecholamine secretion is thus chronically elevated (Figure 1). ${ }^{9,11,96}$ This emerging crucial role for adrenal GRK2 in HF is underlined by the fact that its specific inhibition, via adenoviral-mediated $\beta$ ARKct adrenal gene delivery (see above), leads to a significant reduction in circulating catecholamine levels, restoring not only adrenal, but also cardiac function in $\mathrm{HF} .{ }^{95}$ Additional evidence for the crucial role of adrenal GRK2-regulated $\alpha_{2}$ ARs in regulating adrenal SNS tone in HF comes from the phenylethanolamineN-methyl transferase (PNMT)-driven GRK2 knockout (KO) mice. ${ }^{97}$ These mice, which do not express GRK2 in their adrenal medullae from birth, display decreased SNS outflow and circulating catecholamines in response to myocardial infarction, which translates into preserved cardiac function and morphology over the course of the ensuing $\mathrm{HF}^{97} \mathrm{Of}$ note, elevated GRK2-dependent $\alpha_{2}$ AR dysfunction during HF might also occur in other peripheral sympathetic nerve terminals of the heart (Figure 1) and of other organs, thus contributing to the increased NE release and spillover, as well as to the presynaptic $\alpha_{2}$ AR dysfunction in SNS neurons observed in chronic HF (see $\alpha_{2}$ AR signaling targets for HF therapy). ${ }^{9,11}$ Thus, GRK2 inhibition poses not only as a positive inotropic therapy in the heart per se, but also as a novel sympatholytic strategy in $\mathrm{HF}$, blocking catecholamine release at the sources of these hormones (ie, adrenals and cardiac SNS terminals) and preventing their toxic effects on peripheral organs, like the heart. In addition, adrenal $\beta$ ARKct expression might have a synergistic action with $\beta$-blockers, as both of these therapeutic strategies target adrenergic hyperactivity in HF (Figure 1 and Table 1).

\section{Barr targets for HF therapy}

$\beta$ arrs comprise two ubiquitously expressed isoforms, $\beta$ arr1 and $\beta$ arr2 (arrestin-2 and -3 respectively), both of which are abundantly expressed in cardiac muscle. ${ }^{98}$ As co-factors of GRKs in $\beta A R$ desensitization/downregulation, they contribute to the diminished inotropic and adrenergic reserves of the failing heart and their inhibition should theoretically be beneficial in acute HF, as it would enhance the $\mathrm{G}_{\mathrm{s}}-\mathrm{AC}-\mathrm{PKA}$ axis of pro-contractile signaling of cardiac $\beta$ ARs (see $\beta A R$ signaling targets for HF therapy), thereby increasing cardiac contractility. ${ }^{98}$ However, $\beta$ arrs do not merely terminate $G$ protein-mediated signaling by GPCRs. It is now well established that they promote signaling in their own right, independently of $\mathrm{G}$ proteins, and a number of recent studies point to a beneficial role played by them in the heart, especially when they engage the cardiac $\beta_{1}$ AR. ${ }^{99}$ More specifically, they have been reported to mediate epidermal growth factor receptor (EGFR) transactivation by the $\beta_{1}$ AR. ${ }^{99}$ Consistent with this, a mutant $\beta_{1}$ AR lacking 14 GRK phosphorylation sites in its C-terminal tail that cannot undergo $\beta$ arr-dependent desensitization, fails to transactivate the EGF receptors. ${ }^{100}$ In response to chronic isoproterenol stimulation, transgenic mice expressing this $\beta_{1} \mathrm{AR}$ mutant develop severe dilated cardiomyopathy with significantly increased LV dilatation, decreased fractional shortening, and increased myocardial apoptosis compared with wild-type $\beta_{1}$ AR-expressing transgenic mice. ${ }^{100}$ In this model, inhibition of EGF receptors worsens the dilated cardiomyopathy, suggesting a protective rather than deleterious role for transactivated EGFRs in the heart and prompting the investigators to speculate that $\beta$ arrdependent EGFR transactivation exerts a cardioprotective effect and thus, $\beta$ arr-mediated (in contrast to the classical G protein-dependent) $\beta_{1}$ AR signaling might be of therapeutic benefit in HF (Figure 1 and Table 1)..$^{99,100}$

Effects of cardiac ßarr-dependent signaling can be quite different when the $\mathrm{AT}_{1} \mathrm{R}$ is bound by $\beta$ arrs, An artificially constructed $\mathrm{AT}_{1 \mathrm{~A}} \mathrm{R}$ mutant (AT1-i2m), which fails to activate $\mathrm{G}$ proteins but nonetheless interacts with $\beta$ arrs, activates the mitogenic Src-Ras-ERK1/2 pathway in vitro. ${ }^{101}$ In vivo, cardiomyocyte-specific overexpression of this receptor mutant leads to greater cardiomyocyte hypertrophy, bradycardia, and fetal cardiac gene expression than comparable overexpression of the wild-type receptor. ${ }^{101}$ Conversely, overexpressed wild-type $\mathrm{AT}_{1 \mathrm{~A}} \mathrm{R}$ produces greater cardiomyocyte apoptosis and interstitial fibrosis than the G protein-uncoupled mutant, 
suggesting that $\mathrm{G}$ protein-dependent and -independent $\mathrm{AT}_{1 \mathrm{~A}} \mathrm{R}$ signals mediate different aspects of the hypertrophic response. ${ }^{101}$ Of course, these studies do not directly implicate ßarr signaling; another series of studies using the AngII peptide analog SII ([Sar $\left.{ }^{1}-\mathrm{Il}^{4}-\mathrm{Ile}^{8}\right]$-AngII), which, when bound to the $A T_{1 A} R$, elicits $\beta$ arr signaling but no $G_{q}$ protein signaling, ${ }^{98}$ provide direct evidence for potential roles of $\beta$ arrs in cardiac $\mathrm{AT}_{1 \mathrm{~A}} \mathrm{R}$ signaling. Several studies have shown that $\mathrm{AT}_{1} \mathrm{R}$ ßarr-dependent signaling in cardiac myocytes leads to cardiomyocyte proliferation without hypertrophy (which requires $\mathrm{G}_{\mathrm{q} / 11}$ protein signaling) and can even result in positive inotropy and lusitropy. ${ }^{102}$ These effects require GRK6 and $\beta$ arr2, whereas GRK2 seems to oppose them, consistent with the specialized role of GRK isoforms described in a transfected system. ${ }^{102}$ On the other hand, AT ${ }_{1}$ R-bound $\beta$ arrs do not produce inotropic or chronotropic effects in isolated Langendorff-perfused cardiac preparations despite activating ERK1/2. ${ }^{103}$ Thus, it seems that, while cardiac $\mathrm{AT}_{1} \mathrm{R}$ promotes hypertrophy and cardiomyocyte proliferation via the classical $\mathrm{G}_{\mathrm{q}}$ protein-PKC pathway, it can increase cardiac contractility and function via $\beta$ arr2-dependent signaling (Figure 1). Since $\beta$ arr 2 is bound to stop the $\mathrm{G}$ protein-mediated signaling of the receptor, and GRK2 also seems to oppose this pro-contractile signaling of $\beta$ arr2, it follows that stimulation of $\beta$ arr2 activity and/or GRK2/ $\beta$ arr1 inhibition at the cardiac AT $\mathrm{R}_{1}$ might be of therapeutic value in HF and/or cardiac hypertrophy treatments (Figure 1 and Table 1). ${ }^{8}$ In fact, since $\beta$ arr 1 also mediates $\mathrm{AT}_{1} \mathrm{R}$-induced aldosterone production and secretion in the adrenal cortex (Figure 1), ${ }^{8,104,105}$ ßarr1 inhibition in both the heart and adrenals might be of therapeutic value in chronic HF (Table 1).

\section{Conclusions and future perspectives}

The tremendous progress of molecular biology, physiology, and pharmacology over the past 2 decades or so, coupled with the advent of the first GPCR structures and of the so-called "rational" (ie, target- and structure-based) drug design have provided clinicians and pharmacologists with a tremendous expansion of the therapeutic arsenal for HF. Nevertheless, HF still remains the most devastating, in terms of morbidity, mortality, quality of life, and health care costs, cardiovascular disease and the number one killer in the western world. ${ }^{1-7}$ Thus, new and innovative drugs are desperately needed in order to, if not cure, at least improve quality of life of HF patients. ${ }^{1}$ The field of GPCR signaling keeps providing exciting new possibilities and targets for HF drug development. For instance, targeting intracellular signaling components of the traditional cardiac GPCR drug targets, $\beta$ ARs and AT ${ }_{1}$ Rs, such as heterotrimeric $G$ proteins per se $\left(G_{i}\right.$ protein activation or $\mathrm{G}_{\mathrm{q}}$ protein inhibition), small $\mathrm{G}$ proteins like RhoA, and Epac, might produce novel useful HF drugs. Another exciting avenue for future HF drug development is targeting and exploitation of new GPCRs, the important roles of which in cardiac physiology and pathophysiology keep getting uncovered, such as select adenosine receptor agonism or agonism of certain vasoactive peptide hormone receptors, eg, adrenomedullin, relaxins, or Ucns (CRFR2). In addition, further studies on signaling of cardiac $\alpha_{1}$ ARs, endothelin, and vasopressin receptors, as well as on central and adrenal $\alpha_{2}$ AR signaling, might also finally yield some valid therapeutic targets. Finally, targeting molecules that regulate cardiac GPCR signaling, such as cardiac GRKs and $\beta$ arrs, is perhaps the most exciting area for future HF drug development. For instance, GRK2 inhibition, which can provide a positive inotropic and sympatholytic therapy at the same time, has the potential to revolutionize current chronic HF therapy. On the other hand, as the physiological relevance of cardiac $\beta$ arr signaling becomes fully elucidated, selective targeting of

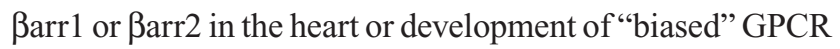
ligands, which selectively recruit $\beta$ arrs over $G$ proteins (or vice versa) at cardiac GPCRs, ${ }^{98}$ will also offer attractive options for future HF drug development. The research conducted to date already indicates that inhibition of $\beta$ arr 1 or stimulation of $\beta$ arr2 in the heart per se might be beneficial for cardiac function and in HF. Future studies will help clarify the picture regarding the potential of cardiac GRK2 and $\beta$ arr targeting for HF treatment. Nonetheless, cardiac GPCR signal transduction appears to be among the research fields that currently hold the largest potential and the biggest promise for the future of HF drug design and development.

\section{Acknowledgments}

AL is supported by a Scientist Development Grant from the American Heart Association (AHA No 09SDG2010138, National Center).

\section{Disclosure}

The authors report no conflicts of interest in this work.

\section{References}

1. Kaye DM, Krum H. Drug discovery for heart failure: a new era or the end of the pipeline? Nat Rev Drug Disc. 2007;6(2):127-139.

2. Swedberg K, Cleland J, Dargie H, et al; Task Force for the Diagnosis and Treatment of Chronic Heart Failure of the European Society of Cardiology. Guidelines for the diagnosis and treatment of chronic heart failure: executive summary (update 2005): the Task Force for the Diagnosis and Treatment of Chronic Heart Failure of the European Society of Cardiology. Eur Heart J. 2005;26(11):1115-1140. 
3. Abhayaratna W, Smith WT, Becker NG, Marwick TH, Jeffery IM, McGill DA. Prevalence of heart failure and systolic ventricular dysfunction in older Australians: the Canberra Heart Study. Med J Aust. 2006;184(4):151-154.

4. Levy D, Kenchaiah S, Larson MG, et al. Long-term trends in the incidence of and survival with heart failure. N Engl J Med. 2002;347(18): $1397-1402$.

5. Roger VL, Weston SA, Redfield MM, et al. Trends in heart failure incidence and survival in a community-based population. JAMA. 2004;292(3):344-350.

6. Mosterd A, Hoes AW, de Bruyne MC, et al. Prevalence of heart failure and left ventricular dysfunction in the general population; the Rotterdam Study. Eur Heart J. 1999;20(6):447-455.

7. Cleland JG, Khand A, Clark A. The heart failure epidemic: exactly how big is it? Eur Heart J. 2001;22(8):623-626.

8. Lymperopoulos A, Bathgate A. Arrestins in the cardiovascular system. Prog Mol Biol Transl Sci. 2013;118:297-334.

9. Lymperopoulos A, Rengo G, Koch WJ. Adrenergic nervous system in heart failure: pathophysiology and therapy. Circ Res. 2013;113: 739-753.

10. Lin HH. G-protein-coupled receptors and their (Bio) chemical significance win 2012 Nobel Prize in chemistry. Biomed J. 2013;36(3): $118-124$.

11. Lymperopoulos A, Rengo G, Koch WJ. GRK2 inhibition in heart failure: something old, something new. Curr Pharm Des. 2012;18(2): 186-191.

12. Skeberdis VA, Gendviliene V, Zablockaite D, et al. Beta3-adrenergic receptor activation increases human atrial tissue contractility and stimulates the L-type Ca2+ current. J Clin Invest. 2008;118(9): 3219-3227.

13. Gauthier C, Leblais V, Kobzik L, et al. The negative inotropic effect of beta3-adrenoceptor stimulation is mediated by activation of a nitric oxide synthase pathway in human ventricle. J Clin Invest. 1998;102(7): $1377-1384$.

14. Rozec B, Erfanian M, Laurent K, Trochu JN, Gauthier C. Nebivolol, a vasodilating selective beta(1)-blocker, is a beta(3)-adrenoceptor agonist in the nonfailing transplanted human heart. $\mathrm{J} \mathrm{Am} \mathrm{Coll} \mathrm{Cardiol.}$ 2009;53(17):1532-1538.

15. Bers DM. Calcium cycling and signaling in cardiac myocytes. Annu Rev Physiol. 2008;70:23-49.

16. Daaka Y, Luttrell LM, Lefkowitz RJ. Switching of the coupling of the beta2-adrenergic receptor to different $\mathrm{G}$ proteins by protein kinase A. Nature. 1997;390(6655):88-91.

17. Movsesian MA, Kukreja RC. Phosphodiesterase inhibition in heart failure. Handb Exp Pharmacol. 2011;(204):237-249.

18. Communal C, Singh K, Sawyer DB, Colucci WS. Opposing effects of beta(1)- and beta(2)-aadrenergic receptors on cardiac myocyte apoptosis: role of a pertussis toxin-sensitive $\mathrm{G}$ protein. Circulation. 1999;100(22):2210-2212.

19. Chesley A, Lundberg MS, Asai T, et al. The beta(2)-adrenergic receptor delivers an antiapoptotic signal to cardiac myocytes through G(i)-dependent coupling to phosphatidylinositol 3'-kinase. Circ Res. 2000;87(12):1172-1179.

20. Zhu WZ, Zheng M, Koch WJ, Lefkowitz RJ, Kobilka BK, Xiao RP. Dual modulation of cell survival and cell death by beta(2)-adrenergic signaling in adult mouse cardiac myocytes. Proc Natl Acad Sci U SA. 2001;98(4):1607-1612.

21. Dorn GW 2nd, Tepe NM, Lorenz JN, Koch WJ, Liggett SB. Lowand high-level transgenic expression of beta2-adrenergic receptors differentially affect cardiac hypertrophy and function in Galphaqoverexpressing mice. Proc Natl Acad Sci U S A. 1999;96(11): 6400-6405.

22. Liggett SB, Tepe NM, Lorenz JN, et al. Early and delayed consequences of beta(2)-adrenergic receptor overexpression in mouse hearts: critical role for expression level. Circulation. 2000;101(14): $1707-1714$.
23. Bristow MR, Ginsburg R, Umans V, et al. Beta 1- and beta 2-adrenergicreceptor subpopulations in nonfailing and failing human ventricular myocardium: coupling of both receptor subtypes to muscle contraction and selective beta 1-receptor down-regulation in heart failure. Circ Res. 1986;59(3):297-309.

24. Bristow MR, Ginsburg R, Minobe W, et al. Decreased catecholamine sensitivity and beta-adrenergic receptor density in failing human hearts. N Engl J Med. 1982;307(4):205-211.

25. Nikolaev VO, Moshkov A, Lyon AR, et al. Beta2-adrenergic receptor redistribution in heart failure changes cAMP compartmentation. Science. 2010;327(5973):1653-1657.

26. Iaccarino G, Tomhave ED, Lefkowitz RJ, Koch WJ. Reciprocal in vivo regulation of myocardial $\mathrm{G}$ protein-coupled receptor kinase expression by beta-adrenergic receptor stimulation and blockade. Circulation. 1998;98(17):1783-1789.

27. Adamson PB, Gilbert EM. Reducing the risk of sudden death in heart failure with beta-blockers. J Card Fail. 2006;12(9):734-746.

28. Birks EJ, Tansley PD, Hardy J, et al. Left ventricular assist device and drug therapy for the reversal of heart failure. $N$ Engl J Med. 2006;355(18):1873-1884.

29. DiNicolantonio JJ, Lavie CJ, Fares H, Menezes AR, O'Keefe JH. Meta-analysis of carvedilol versus beta 1 selective beta-blockers (atenolol, bisoprolol, metoprolol, and nebivolol). Am J Cardiol. 2013; 111(5):765-769.

30. Woodcock EA, Du XJ, Reichelt ME, Graham RM. Cardiac alpha 1 -adrenergic drive in pathological remodelling. Cardiovasc Res. 2008;77(3):452-462.

31. Shannon R, Chaudhry M. Effect of alpha1-adrenergic receptors in cardiac pathophysiology. Am Heart J. 2006;152(5):842-850.

32. Knowlton KU, Michel MC, Itani M, et al. The alpha 1 A-adrenergic receptor subtype mediates biochemical, molecular, and morphologic features of cultured myocardial cell hypertrophy. J Biol Chem. 1993; 268(21):15374-15380.

33. Du XJ, Gao XM, Kiriazis H, et al. Transgenic alpha1 A-adrenergic activation limits post-infarct ventricular remodeling and dysfunction and improves survival. Cardiovasc Res. 2006;71(4):735-743.

34. Huang Y, Wright CD, Merkwan CL, et al. An alpha1 A-adrenergic extracellular signal-regulated kinase survival signaling pathway in cardiac myocytes. Circulation. 2007;115(6):763-772.

35. Esposito G, Prasad SV, Rapacciuolo A, Mao L, Koch WJ, Rockman HA. Cardiac overexpression of a G(q) inhibitor blocks induction of extracellular signal-regulated kinase and c-Jun $\mathrm{NH}(2)$-terminal kinase activity in in vivo pressure overload. Circulation. 2001;103(10):1453-1458.

36. Hwang H, Robinson DA, Stevenson TK, et al. PKC $\beta I I$ modulation of myocyte contractile performance. J Mol Cell Cardiol. 2012; 53(2):176-186.

37. Philipp M, Hein L. Adrenergic receptor knockout mice: distinct functions of 9 receptor subtypes. Pharmacol Ther. 2004;101(1):65-74.

38. Philipp M, Brede M, Hein L. Physiological significance of alpha(2)adrenergic receptor subtype diversity: one receptor is not enough. Am J Physiol Regul Integr Comp Physiol. 2002;283(2):R287-R295.

39. Hein L, Altman JD, Kobilka BK. Two functionally distinct alpha2adrenergic receptors regulate sympathetic neurotransmission. Nature. 1999;402(6758):181-184.

40. Brede M, Wiesmann F, Jahns R, et al. Feedback inhibition of catecholamine release by two different alpha2-adrenoceptor subtypes prevents progression of heart failure. Circulation. 2002;106(19):2491-2496.

41. Brede M, Nagy G, Philipp M, Sorensen JB, Lohse MJ, Hein L. Differential control of adrenal and sympathetic catecholamine release by alpha2adrenoceptor subtypes. Mol Endocrinol. 2003;17(8):1640-1646.

42. Lymperopoulos A, Rengo G, Koch WJ. Adrenal adrenoceptors in heart failure: fine-tuning cardiac stimulation. Trends Mol Med. 2007;13(12):503-511.

43. Small KM, Wagoner LE, Levin AM, Kardia SL, Liggett SB. Synergistic polymorphisms of beta 1 - and alpha2C-adrenergic receptors and the risk of congestive heart failure. $N$ Engl J Med. 2002;347(15):1135-1142. 
44. Neumeister A, Charney DS, Belfer I, et al. Sympathoneural and adrenomedullary functional effects of alpha2C-adrenoceptor gene polymorphism in healthy humans. Pharmacogenet Genomics. 2005;15(3): 143-149.

45. Cohn JN, Levine TB, Olivari M T, et al. Plasma norepinephrine as a guide to prognosis in patients with chronic congestive heart failure. N Engl J Med. 1984;311(13):819-823.

46. Floras JS. The "unsympathetic" nervous system of heart failure. Circulation. 2002;105(15):1753-1755.

47. Rengo G, Lymperopoulos A, Zincarelli C, et al. Myocardial adenoassociated virus serotype 6-betaARKct gene therapy improves cardiac function and normalizes the neurohormonal axis in chronic heart failure. Circulation. 2009;119(1):89-98.

48. Port JD, Bristow MR. Altered beta-adrenergic receptor gene regulation and signaling in chronic heart failure. J Mol Cell Cardiol. 2001;33(5): 887-905.

49. Bristow MR. Beta-adrenergic receptor blockade in chronic heart failure. Circulation. 2000;101(5):558-569.

50. Cohn JN, Pfeffer MA, Rouleau J, et al; the MOXCON Investigators Adverse mortality effect of central sympathetic inhibition with sustained-release moxonidine in patients with heart failure (MOXCON). Eur J Heart Fail. 2003;5(5):659-667.

51. Kao DP, Wagner BD, Robertson AD, Bristow MR, Lowes BD. A personalized BEST: characterization of latent clinical classes of nonischemic heart failure that predict outcomes and response to bucindolol. PLoS One. 2012;7(11):e48184.

52. Aggarwal A, Esler MD, Socratous F, Kaye DM. Evidence for functional presynaptic alpha-2 adrenoceptors and their down-regulation in human heart failure. J Am Coll Cardiol. 2001;37(5):1246-1251.

53. CONSENSUS Trial Study Group. Effects of enalapril on mortality in severe congestive heart failure. Results of the Cooperative North Scandinavian Enalapril Survival Study (CONSENSUS). The CONSENSUS Trial Study Group. N Engl J Med. 1987;316(23):1429-1435.

54. Cohn JN, Johnson G, Ziesche S, et al. A comparison of enalapril with hydralazine-isosorbide dinitrate in the treatment of chronic congestive heart failure. N Engl J Med. 1991;325(5):303-310.

55. Francis GS, Benedict C, Johnstone DE, et al. Comparison of neuroendocrine activation in patients with left ventricular dysfunction with and without congestive heart failure. A substudy of the Studies of Left Ventricular Dysfunction (SOLVD). Circulation. 1990;82(5): 1724-1729.

56. Weber K. Extracellular matrix remodeling in heart failure: a role for de novo angiotensin II generation. Circuation. 1997;96(11): 4065-4082.

57. Schieffer B, Wirger A, Meybrunn M, et al. Comparative effects of chronic angiotensin-converting enzyme inhibition and angiotensin II type 1 receptor blockade on cardiac remodeling after myocardial infarction in the rat. Circulation. 1994;89(5):2273-2282.

58. Lang CC, Struthers AD. Targeting the renin-angiotensin-aldosterone system in heart failure. Nat Rev Cardiol. 2013;10( 3):125-134.

59. Kaoukis A, Deftereos S, Raisakis K, et al. The role of endothelin system in cardiovascular disease and the potential therapeutic perspectives of its inhibition. Curr Top Med Chem. 2013;13(2):95-114.

60. Kaluski E, Kobrin I, Zimlichman R, et al. RITZ-5: randomized intravenous TeZosentan (an endothelin-A/B antagonist) for the treatment of pulmonary edema: a prospective, multicenter, double-blind, placebo-controlled study. J Am Coll Cardiol. 2003;41(2):204-210.

61. Mustafa SJ, Morrison RR, Teng B, Pelleg A. Adenosine receptors and the heart: role in regulation of coronary blood flow and cardiac electrophysiology. Handb Exp Pharmacol. 2009;(193):161-188.

62. Nell PG, Albrecht-Küpper B. The adenosine A1 receptor and its ligands. Prog Med Chem. 2009;47:163-201.

63. Sabbah HN, Gupta RC, Kohli S, et al. Chronic therapy with a partial adenosine A1-receptor agonist improves left ventricular function and remodeling in dogs with advanced heart failure. Circ Heart Fail. 2013;6(3):563-571.
64. Nishikimi T, Kuwahara K, Nakagawa Y, Kangawa K, Nakao K Adrenomedullin in cardiovascular disease: a useful biomarker, its pathological roles and therapeutic application. Curr Protein Pept Sci. 2013;14(4):256-267.

65. Hong Y, Hay DL, Quirion R, Poyner DR. The pharmacology of adrenomedullin 2/intermedin. Br J Pharmacol. 2012;166(1):110-120.

66. Yoshizawa T, Sakurai T, Kamiyoshi A, et al. Novel regulation of cardiac metabolism and homeostasis by the adrenomedullin-receptor activitymodifying protein 2 system. Hypertension. 2013;61(2):341-351.

67. Bathgate RA, Halls ML, van der Westhuizen ET, Callander GE, Kocan M, Summers RJ. Relaxin family peptides and their receptors. Physiol Rev. 2013;93(1):405-480.

68. Metra M, Cotter G, Davison BA, et al. Effect of serelaxin on cardiac, renal, and hepatic biomarkers in the Relaxin in Acute Heart Failure (RELAX-AHF) development program: correlation with outcomes. J Am Coll Cardiol. 2013;61(2):196-206.

69. Wang J, Li S. Corticotropin-releasing factor family and its receptors: tumor therapeutic targets? Biochem Biophys Res Commun. 2007;362(4): 785-788.

70. Emeto TI, Moxon JV, Rush C, Woodward L, Golledge J. Relevance of urocortins to cardiovascular disease. J Mol Cell Cardiol. 2011;51(3): 299-307.

71. Davis ME, Pemberton CJ, Yandle TG, et al. Urocortin 2 infusion in human heart failure. Eur Heart J. 2007;28(21):2589-2597.

72. Gheorghiade M, Greene SJ, Ponikowski P, et al. Haemodynamic effects, safety, and pharmacokinetics of human stresscopin in heart failure with reduced ejection fraction. Eur J Heart Fail. 2013;15(6):679-689.

73. Holmes CL, Landry DW, Granton JT. Science review: Vasopressin and the cardiovascular system part 1. Receptor physiology. Crit Care. 2003;7(6):427-434.

74. Gassanov N, Semmo N, Semmo M, Nia AM, Fuhr U, Er F. Arginine vasopressin (AVP) and treatment with arginine vasopressin receptor antagonists (vaptans) in congestive heart failure, liver cirrhosis and syndrome of inappropriate antidiuretic hormone secretion (SIADH). Eur J Clin Pharmacol. 2011;67(4):333-346.

75. Ambrosy AP, Vaduganathan M, Mentz RJ, et al. Clinical profile and prognostic value of low systolic blood pressure in patients hospitalized for heart failure with reduced ejection fraction: insights from the Efficacy of Vasopressin Antagonism in Heart Failure: Outcome Study with Tolvaptan (EVEREST) trial. Am Heart J. 2013;165(2):216-225.

76. Kinugawa K, Imamura T, Komuro I. Experience of a vasopressin receptor antagonist, tolvaptan under the unique indication in Japanese heart failure patients. Clin Pharmacol Ther. Epub July 19, 2013.

77. Ussher JR, Drucker DJ. Cardiovascular biology of the incretin system. Endocr Rev. 2012;33(2):187-215.

78. Lorber D. GLP-1 receptor agonists: effects on cardiovascular risk reduction. Cardiovasc Ther. 2013;31(4):238-249.

79. Brubaker PL. Minireview: update on incretin biology: focus on glucagon-like peptide-1. Endocrinology. 2010;151(5):1984-1989.

80. Surma M, Wei L, Shi J. Rho kinase as a therapeutic target in cardiovascular disease. Future Cardiol. 2011;7(5):657-671.

81. Hattori T, Shimokawa H, Higashi M, et al. Long-term inhibition of Rho-kinase suppresses left ventricular remodeling after myocardial infarction in mice. Circulation. 2004;109(18):2234-2239.

82. McKinsey TA, Kass DA. Small-molecule therapies for cardiac hypertrophy: moving beneath the cell surface. Nat Rev Drug Discov. 2007;6(8):617-635.

83. Schmidt M, Dekker FJ, Maarsingh H. Exchange protein directly activated by cAMP (epac): a multidomain cAMP mediator in the regulation of diverse biological functions. Pharmacol Rev. 2013;65(2):670-709.

84. Pereira L, Cheng H, Lao DH, et al. Epac2 mediates cardiac $\beta 1$-adrenergic-dependent sarcoplasmic reticulum $\mathrm{Ca} 2+$ leak and arrhythmia. Circulation. 2013;127(8):913-922.

85. Reiter E, Lefkowitz RJ. GRKs and beta-arrestins: roles in receptor silencing, trafficking and signaling. Trends Endocrinol Metab. 2006;17(4):159-165. 
86. Ferguson SS. Evolving concepts in G protein-coupled receptor endocytosis: the role in receptor desensitization and signaling. Pharmacol Rev. 2001;53(1):1-24.

87. Arriza JL, Dawson TM, Simerly RB, et al. The G-protein-coupled receptor kinases beta ARK1 and beta ARK2 are widely distributed at synapses in rat brain. J Neurosci. 1992;12(10):4045-4055.

88. Rockman HA, Koch WJ, Lefkowitz RJ. Seven-transmembrane-spanning receptors and heart function. Nature. 2002;415(6868):206-212.

89. Belmonte SL, Blaxall BC. G protein coupled receptor kinases as therapeutic targets in cardiovascular disease. Circ Res. 2011;109(3):309-319.

90. Rengo G, Lymperopoulos A, Leosco D, Koch WJ. GRK2 as a novel gene therapy target in heart failure. J Mol Cell Cardiol. 2011;50(5): 785-792.

91. Ungerer M, Böhm M, Elce JS, Erdmann E, Lohse MJ. Altered expression of beta-adrenergic receptor kinase and beta 1-adrenergic receptors in the failing human heart. Circulation. 1993;87(2):454-463.

92. Koch WJ, Rockman HA, Samama P, et al. Cardiac function in mice overexpressing the beta-adrenergic receptor kinase or a beta ARK inhibitor. Science. 1995;268(5215):1350-1353.

93. Thal DM, Homan KT, Chen J, et al. Paroxetine is a direct inhibitor of $g$ protein-coupled receptor kinase 2 and increases myocardial contractility. ACS Chem Biol. 2012;7(11):1830-1839.

94. Eschenhagen T. Beta-adrenergic signaling in heart failure: adapt or die. Nat Med. 2008;14(5):485-487.

95. Lymperopoulos A, Rengo G, Funakoshi H, Eckhart AD, Koch WJ. Adrenal GRK2 upregulation mediates sympathetic overdrive in heart failure. Nat Med. 2007;13(3):315-323.

96. Lymperopoulos A, Bathgate A. Pharmacogenomics of the heptahelical receptor regulators G-protein-coupled receptor kinases and arrestins: the known and the unknown. Pharmacogenomics. 2012;13(3):323-341.

97. Lymperopoulos A, Rengo G, Gao E, Ebert SN, Dorn GW 2nd, Koch WJ. Reduction of sympathetic activity via adrenal-targeted GRK2 gene deletion attenuates heart failure progression and improves cardiac function after myocardial infarction. J Biol Chem. 2010; 285(21):16378-16386.
98. Lymperopoulos A. Beta-arrestin biased agonism/antagonism at cardiovascular seven transmembrane-spanning receptors. Curr Pharm Des. 2012;18(2):192-198.

99. Noor N, Patel CB, Rockman HA. B-arrestin: a signaling molecule and potential therapeutic target for heart failure. J Mol Cell Cardiol. 2011;51(4):534-541.

100. Tilley DG. G protein-dependent and $G$ protein-independent signaling pathways and their impact on cardiac function. Circ Res. 2011;109(2): 217-230.

101. Zhai P, Yamamoto M, Galeotti J, et al. Cardiac-specific overexpression of AT1 receptor mutant lacking $G$ alpha $q / G$ alpha i coupling causes hypertrophy and bradycardia in transgenic mice. J Clin Invest. 2005;115(11):3045-3056.

102. Rajagopal K, Whalen EJ, Violin JD, et al. Beta-arrestin2-mediated inotropic effects of the angiotensin II type 1A receptor in isolated cardiac myocytes. Proc Natl Acad Sci U S A. 2006;103(44): 16284-16289.

103. Aplin M, Christensen GL, Schneider M, et al. Differential extracellular signal-regulated kinases 1 and 2 activation by the angiotensin type 1 receptor supports distinct phenotypes of cardiac myocytes. Basic Clin Pharmacol Toxicol. 2007;100(5):296-301.

104. Lymperopoulos A, Rengo G, Zincarelli C, Kim J, Soltys S, Koch WJ. An adrenal beta-arrestin 1-mediated signaling pathway underlies angiotensin II-induced aldosterone production in vitro and in vivo. Proc Natl Acad Sci U S A. 2009;106(14):5825-5830.

105. Lymperopoulos A, Rengo G, Zincarelli C, Kim J, Koch WJ. Adrenal Beta-arrestin 1 inhibition in vivo attenuates post-myocardial infarction progression to heart failure and adverse remodeling via reduction of circulating aldosterone levels. J Am Coll Cardiol. 2011;57(3): $356-365$.
Drug Design, Development and Therapy

\section{Publish your work in this journal}

Drug Design, Development and Therapy is an international, peerreviewed open-access journal that spans the spectrum of drug design and development through to clinical applications. Clinical outcomes, patient safety, and programs for the development and effective, safe, and sustained use of medicines are a feature of the journal, which

\section{Dovepress}

has also been accepted for indexing on PubMed Central. The manuscript management system is completely online and includes a very quick and fair peer-review system, which is all easy to use. Visit http://www.dovepress.com/testimonials.php to read real quotes from published authors. 